\title{
Surface-soil structural properties under grass and cereal production on a Mollic Cyroboralf in Canada
}

\author{
M.A. Arshad ${ }^{a, b, *}$, A.J. Franzluebbers ${ }^{c}$, R.H. Azooz ${ }^{a}$ \\ ${ }^{a}$ Agriculture and Agri-Food Canada, P.O. Box 29, Beaverlodge, Alta., Canada TOH OCO \\ ${ }^{\mathrm{b}}$ Department of Renewable Resources, University of Alberta, Edmonton, Alta., Canada T6G $2 \mathrm{HI}$ \\ ${ }^{c}$ USDA-Agricultural Research Service, 1420 Experiment Station Road, Watkinsville, GA 30677, USA
}

Received 28 May 2003; received in revised form 2 October 2003; accepted 15 October 2003

\begin{abstract}
Conservation tillage has become a major soil management strategy to reduce soil erosion and improve soil quality, yet the impacts of crop rotation on soil responses to conservation tillage remain poorly described. We investigated the effects of (i) perennial grass cover versus annual cropping and (ii) type of break crop in a wheat (Triticum aestivum L.)-based crop rotation system on surface-soil $(0-10 \mathrm{~cm})$ structural and organic matter properties towards the end of a decade of continuous management on an Albic Luvisol in the cold, semiarid region of northwestern Canada. Soil aggregation was at state to resist water erosion more under perennial grass (i.e. bromegrass (Bromus inermis Leyss.) and red fescue (Festuca rubra L.)) than under annual cropping systems (mean-weight diameter of 2.1 and $1.6 \mathrm{~mm}$ under perennial and annual systems, respectively). Soil organic $\mathrm{C}$ was higher $\left(44 \mathrm{~g} \mathrm{C} \mathrm{kg}^{-1}\right.$ soil versus $38 \mathrm{~g} \mathrm{C} \mathrm{kg}^{-1}$ soil), but total soil $\mathrm{N}$ was lower $\left(3.5 \mathrm{~g} \mathrm{~N} \mathrm{~kg}^{-1}\right.$ soil versus $3.9 \mathrm{~g} \mathrm{~N} \mathrm{~kg}^{-1}$ soil) under perennial compared with annual cropping systems. There were few significant differences in soil-structural properties among the various annual cropping systems. The largest effect was greater light-fraction $\mathrm{C}$ and $\mathrm{N}$ under continuous wheat $\left(4.0 \mathrm{~g} \mathrm{C} \mathrm{kg}^{-1}\right.$ soil and $0.27 \mathrm{~g} \mathrm{~N} \mathrm{~kg}^{-1}$ soil) compared with other rotations, especially wheat-wheat-fallow $\left(2.4 \mathrm{~g} \mathrm{C} \mathrm{kg}^{-1}\right.$ soil and $0.16 \mathrm{~g} \mathrm{~N} \mathrm{~kg}^{-1}$ soil), as a result of higher residue inputs. Relationships between mean-weight diameter of water-stable aggregates and biochemical properties were strongest for soil microbial biomass $\mathrm{C}$ and soil organic $\mathrm{C}$. Perennial grass cover exhibited greater potential to preserve soil-structural properties than no-tillage annual cropping.
\end{abstract}

(c) 2003 Elsevier B.V. All rights reserved.

Keywords: Aggregation; Bulk density; Hay; Microbial biomass; Penetration resistance; Soil organic carbon; Wheat

\section{Introduction}

Various crop management strategies are used to increase and sustain crop production and enhance soil quality. Effective strategies that meet production and conservation goals often include reduced tillage

\footnotetext{
* Corresponding author. Tel.: +1-780-492-6921; fax: $+1-780-492-4323$.

E-mail address: charlie.arshad@ualberta.ca (M.A. Arshad).
}

and legume- or forage-based crop rotations. The effects of crop rotations and reduced tillage are often site-specific (Arshad et al., 2002). Factors that can be influenced by crop selection and rotation include soil structure, aggregation, bulk density, water infiltration, water retention, erodibility, and soil organic matter (Karlen and Cambardella, 1996). The benefits of crop rotation on the quantity and quality of soil organic matter are well documented (McGill et al., 1986; Janzen, 1987; Campbell et al., 1990, 1996). 
Changes in the quantity and quality of soil organic matter resulting from decomposition of crop residue inputs depend on the initial level of soil organic matter, a variety of soil physical and chemical components, previous cropping, tillage (depth and intensity) history, production inputs, weather conditions, and a variety of other factors (Campbell et al., 1996). The type of crop and/or tillage practice also affects soil structure and hydraulic properties. For example, many researchers have reported a significant increase in water-stable aggregates within 2-3 years following conversion of conventionally tilled soil to no-tillage management (Arshad et al., 1998; Angers et al., 1992; Chan and Mead, 1986).

Loss of soil organic C following cultivation of grassland has been attributed to the destruction of macroaggregates and subsequent mineralization of labile organic $\mathrm{C}$, largely from these macroaggregates (Elliott, 1986). Fallow frequency in the semiarid prairie region has been reported to be the dominant factor influencing labile organic matter such as light-fraction organic $\mathrm{C}$ and $\mathrm{N}$, mineralizable $\mathrm{C}$ and $\mathrm{N}$, and water-soluble C (Campbell et al., 1999). Variable results in these responses have been a consequence of differences in soil moisture, temperature, precipitation, and rhizodeposition among evaluation periods.

In the far northern region of the North American prairies, field experiments were established in the early 1990s to determine the impact of the type of crop production system on crop yield, with greater emphasis on conservation tillage and legume- and forage-based crop rotations as possible controlling factors. Limited data are available on the influence of crop rotations on soil biochemical attributes and their interaction with soil physical properties. Our objective was to evaluate the medium-term (10-11 years) effect of several crop rotations managed under no-tillage on soil structure, soil organic $\mathrm{C}$ storage, and quality of organic $\mathrm{C}$ and $\mathrm{N}$.

\section{Materials and methods}

\subsection{Site characteristics}

The experimental site was established in 1992 on an Albright silt loam (Dark Gray Luvisol (Soil Classification Working Group, 1998); fine, montmor- rilonitic, frigid Mollic Cryoboralf (Soil Survey Staff, 1996), Albic Luvisol (FAO)) near Beaverlodge, Alta. $\left(55^{\circ} 12^{\prime} \mathrm{N}, 119^{\circ} 23^{\prime} \mathrm{W}\right)$. Soil characteristics $(0-20 \mathrm{~cm})$ in 1992 were $220 \mathrm{~g} \mathrm{sand} \mathrm{kg}^{-1}, \quad 340 \mathrm{~g} \mathrm{clay} \mathrm{kg}^{-1}$, $38 \mathrm{~g}$ organic $\mathrm{C} \mathrm{kg}^{-1}, 28 \mathrm{cmol}_{\mathrm{c}} \mathrm{kg}^{-1}$, and a $\mathrm{pH}(1: 2$, soil:0.01 $\mathrm{M} \mathrm{CaCl}_{2}$ ) of 5.1. Long-term mean annual temperature is $2{ }^{\circ} \mathrm{C}$, annual precipitation is $452 \mathrm{~mm}$, and pan evaporation is $>800 \mathrm{~mm}$. During 11 years of this study, April through September precipitation was $290 \pm 90 \mathrm{~mm}$.

\subsection{Experimental design and management}

The experimental design was a randomized, complete block design with four replications. Six main-plot treatments included two perennial forages grown continuously (smooth brome (Bromus inermis Leyss.) and red fescue (Festuca rubra L.)), continuous wheat (Triticum aestivum L.), and three wheat rotations (wheat-wheat-fallow, wheat-wheat-canola (Brassica campestris L.), and wheat-wheat-pea (Pisum sativum L.)). Phases of the rotations appeared in each year resulting in three subplots within each wheat rotation. Plots measured $3.5 \mathrm{~m} \times 30 \mathrm{~m}$.

Smooth brome and red fescue were established in 1993 by broadcast seeding $16.7 \mathrm{~kg} \mathrm{ha}^{-1}$ of 'Carleton' smooth brome and $3.7 \mathrm{~kg} \mathrm{ha}^{-1}$ of 'Boreal' red fescue. Grass stands were cut for hay once or twice a year, depending upon weather conditions. Grass stands were unfertilized prior to 2001 and fertilized with $150-44-0 \mathrm{~kg} \mathrm{~N}-\mathrm{P}-\mathrm{Kha}^{-1}$ in June 2001 and with 225-44-0 kg N-P-K ha ${ }^{-1}$ in June 2002.

All annual crops were sown in the first half of May at rates of $100 \mathrm{~kg} \mathrm{ha}^{-1}$ for wheat, $8 \mathrm{~kg} \mathrm{ha}^{-1}$ for canola, and $180 \mathrm{~kg} \mathrm{ha}^{-1}$ for pea with a double-disk seed drill in $0.23 \mathrm{~m}$ wide rows. Seeding depths were $4 \mathrm{~cm}$ for wheat, $1.5 \mathrm{~cm}$ for canola, and $6 \mathrm{~cm}$ for pea. Agronomic practices and production prior to 2000 were described in Arshad et al. (1998, 2002). Cultivars planted from 2000 to 2002 were 'Rablin' wheat, 'Reward' canola, and 'Carneval' and 'Swing' pea. Fertilization was based on local recommendation and soil test results. During 2000-2002, fertilization averaged $102 \pm$ $55 \mathrm{~kg} \mathrm{Nha}^{-1}$ per year and $25 \pm 7 \mathrm{~kg} \mathrm{Pha}^{-1}$ per year to each crop. Pea and canola received $50 \mathrm{~kg} \mathrm{~K}-\mathrm{S} \mathrm{ha}^{-1}$ per year. Crops were harvested during 20-22 September in 2000, 20 August to 5 September in 2001, and 5-12 September in 2002. 
All crops were managed by harrowing following harvest in September-October to evenly distribute straw. Prior to planting the following spring, plots were sprayed with glyphosate to control weeds. Seedbeds were not prepared with tillage. The fallow phase was managed throughout the year with glyphosate to control weeds.

\subsection{Soil sampling and analyses}

Bulk density was determined in October 2001 by compositing five $5 \mathrm{~cm}$ diameter cores per plot. Dry weight at $105^{\circ} \mathrm{C}$ was divided by volume of cores. Soil was sampled for most laboratory analyses following harvest in August 2002 at the end of 11 years of management. Samples $(2.5 \mathrm{~cm}$ diameter) were a composite of eight cores from each plot representing a depth of $0-10 \mathrm{~cm}$. Soil was air-dried and passed through an $8 \mathrm{~mm}$ screen. Soil was also collected in September 1999 in the same manner for determination of light fraction.

Aggregate-size distribution was determined from $50 \mathrm{~g}$ subsamples of air-dried soil directly immersed in water for $10 \mathrm{~min}$ with a stroke length of $35 \mathrm{~mm}$ and a frequency of $16 \mathrm{~min}^{-1}$. Dry weight $\left(50^{\circ} \mathrm{C}\right)$ of soil retained on sieves with openings of 4, 2, 1, 0.5, 0.25, and $0.13 \mathrm{~mm}$ was used to calculate mean-weight diameter (Kemper and Rosenau, 1986). The fraction $<0.13 \mathrm{~mm}$ was calculated as the difference between initial and the sum of the other six fractions.

Light fraction was isolated by flotation following dispersion of soil in $\mathrm{NaI}$ solution with a specific gravity of $1.7 \mathrm{Mg} \mathrm{m}^{-3}$ (Strickland and Sollins, 1987). Subsamples of whole soil, water-stable aggregate fractions, and light fraction were analyzed for total $\mathrm{C}$ and $\mathrm{N}$ by standard acid digestion procedures with external heating (Bremner, 1996; Nelson and Sommers, 1996).

Soil microbial biomass was determined with chloroform fumigation-incubation without subtraction of a control (Jenkinson and Powlson, 1976; Franzluebbers et al., 1999). Following a 10-day pre-incubation period, a $20 \mathrm{~g}$ subsample was fumigated with $\mathrm{CHCl}_{3}$ for $24 \mathrm{~h}$ and subsequently incubated at $22.5 \pm 1{ }^{\circ} \mathrm{C}$ in a 11 sealed glass jar for a further 10 days in the presence of $10 \mathrm{ml}$ of $0.5 \mathrm{M} \mathrm{NaOH}$ to trap evolved $\mathrm{CO}_{2}$. Soil microbial biomass $\mathrm{C}$ was calculated as the quantity of $\mathrm{CO}_{2}$ evolved following fumigation, assuming an efficiency factor of 0.41 (Voroney and Paul, 1984).
Net $\mathrm{N}$ mineralization was calculated as the difference in inorganic $\mathrm{N}$ between 0 and 24 days of incubation at $22.5 \pm 1{ }^{\circ} \mathrm{C}$ and near optimum moisture content (30\% gravimetric water content). Inorganic $\mathrm{N}$ was determined from a $5 \mathrm{~g}$ subsample that was passed through a $2 \mathrm{~mm}$ screen and shaken with $10 \mathrm{ml}$ of $2 \mathrm{M} \mathrm{KCl}$ for $1 \mathrm{~h}$. The filtered extract was analyzed for $\mathrm{NH}_{4}-\mathrm{N}$ and $\mathrm{NO}_{3}-\mathrm{N}+\mathrm{NO}_{2}-\mathrm{N}$ using autoanalyzer techniques with a modified indophenol blue method with citrate buffer and a cadmium reduction method, respectively (Bundy and Meisinger, 1994).

Rate of water infiltration was determined with a constant-head well permeameter on 23 September 2002 (Reynolds et al., 1985). The rate of infiltration was determined from several similar 2-3 min estimates following achievement of steady-state infiltration (varying from 22 to $30 \mathrm{~min}$ ) at five to seven locations within a treatment. Soil penetration resistance was determined by using the Investigator ${ }^{\mathrm{TM}}$ Soil Compaction Meter; probe operated at the rate of 2 seconds per $5 \mathrm{~cm}$ soil depth.

\subsection{Statistical analyses}

Variance in soil properties among the six main plots was analyzed using the general linear model procedure (SAS Institute Inc., 1990). Correlation among response variables was tested $(n=36)$. Significance was declared at $P \leq 0.05$.

\section{Results and discussion}

\subsection{Perennial grass compared with annual crops}

Total organic $\mathrm{C}$ in the surface $10 \mathrm{~cm}$ of soil was greater under perennial grass systems (i.e. smooth brome and red fescue) than under annual cropping systems (i.e. the four wheat systems) $(P=0.001)$ (Table 1). The vigorous perennial root system and undisturbed soil cover could have increased $\mathrm{C}$ input. In addition, opportunities for a longer period of soil water extraction in perennial systems could have reduced soil water content, thereby limiting soil microbial activity and $\mathrm{C}$ output. Many research results support the conclusion that perennial grass systems offer greater soil organic matter accumulation than conventionally tilled annual cropping systems (Haas 
Table 1

Soil chemical and biochemical properties $(0-10 \mathrm{~cm})$ at the end of 11 years of management as affected by cropping system near Beaverlodge, Alta.

\begin{tabular}{|c|c|c|c|c|c|c|c|}
\hline \multirow[t]{2}{*}{ Soil property } & \multirow{2}{*}{$\begin{array}{l}\text { Smooth } \\
\text { brome }\end{array}$} & \multirow{2}{*}{$\begin{array}{l}\text { Red } \\
\text { fescue }\end{array}$} & \multirow{2}{*}{$\begin{array}{l}\text { Continuous } \\
\text { wheat }\end{array}$} & \multicolumn{3}{|c|}{ 3-Year rotation of } & \multirow[t]{2}{*}{$\operatorname{LSD}_{(\mathrm{P} \leq 0.05)}$} \\
\hline & & & & $\begin{array}{l}\text { Wheat-wheat- } \\
\text { canola }\end{array}$ & $\begin{array}{l}\text { Wheat-wheat- } \\
\text { pea }\end{array}$ & $\begin{array}{l}\text { Wheat-wheat- } \\
\text { fallow }\end{array}$ & \\
\hline Total organic $\mathrm{C}\left(\mathrm{g} \mathrm{kg}^{-1}\right)$ & 43 & 45 & 39 & 40 & 37 & 37 & 4 \\
\hline Total $\mathrm{N}\left(\mathrm{g} \mathrm{kg}^{-1}\right)$ & 3.6 & 3.5 & 3.9 & 3.9 & 3.8 & 3.9 & 0.6 \\
\hline Whole-soil C:N $\left(\mathrm{g} \mathrm{g}^{-1}\right)$ & 12.1 & 12.6 & 9.8 & 10.2 & 9.9 & 9.6 & 1.0 \\
\hline Light-fraction $\mathrm{C}\left(\mathrm{g} \mathrm{kg}^{-1}\right)$ & 2.7 & 3.2 & 4.0 & 3.1 & 2.8 & 2.4 & 0.7 \\
\hline Light-fraction $\mathrm{N}\left(\mathrm{g} \mathrm{kg}^{-1}\right)$ & 0.19 & 0.22 & 0.27 & 0.21 & 0.19 & 0.16 & 0.05 \\
\hline $\begin{array}{l}\text { Microbial biomass } \mathrm{C} \\
\quad\left(\mathrm{mg} \mathrm{kg}^{-1}\right)\end{array}$ & 1075 & 1164 & 925 & 855 & 856 & 873 & 91 \\
\hline $\begin{array}{l}\mathrm{N} \text { mineralization } \\
\quad\left(\mathrm{mg} \mathrm{kg}^{-1} \text { per } 24 \text { days }\right)\end{array}$ & 43 & 30 & 26 & 29 & 23 & 19 & 10 \\
\hline Inorganic $\mathrm{N}\left(\mathrm{mg} \mathrm{kg}^{-1}\right)$ & 58 & 37 & 23 & 28 & 16 & 25 & 23 \\
\hline
\end{tabular}

et al., 1957; Janzen et al., 1998; Cihacek and Meyer, 2002). However, the annual crops in our study were seeded with minimum disturbance under no-tillage, which should have limited decomposition compared with inversion tillage methods. There are also some reports available that support our findings of greater total organic $\mathrm{C}$ under perennial grass systems than under conservation-tilled annual crops (Ismail et al., 1994; Franzluebbers et al., 1998, 2000).

Total organic $\mathrm{C}$ and $\mathrm{N}$ are often highly correlated, because of the simultaneous utilization of $\mathrm{C}$ and $\mathrm{N}$ by microorganisms for energy and nutrient metabolism (Jansson and Persson, 1982). However in contrast to the results of total organic $\mathrm{C}$, total soil $\mathrm{N}$ under perennial grass systems was lower than under annual cropping systems (i.e. group-wise comparison, $P=0.05$ ) (Table 1). This reversal of response was likely due to the limited above-ground productivity potential of the perennial grass systems, because of no $\mathrm{N}$ fertilizer inputs during the first 9 years. Total above-ground dry matter production from 1996 to 2000 averaged $2.33 \pm 0.62$ and $7.41 \pm 1.67 \mathrm{Mg} \mathrm{ha}^{-1}$ per year under perennial and annual systems, respectively. Following fertilization of perennial grass beginning in 2001, total dry matter production averaged $3.13 \pm 1.23$ and $5.21 \pm 0.75 \mathrm{Mg} \mathrm{ha}^{-1}$ per year under perennial and annual systems, respectively. Fertilization of bromegrass with $\mathrm{N}$ has been shown to increase soil organic $\mathrm{C}$ sequestration (Nyborg et al., 1997), likely due to stimulation of $\mathrm{C}$ input.
As a result of the variable responses in total organic $\mathrm{C}$ and total soil $\mathrm{N}$, whole-soil $\mathrm{C}: \mathrm{N}$ ratio was higher with perennial grass systems than with annual cropping systems $(P=0.01)$ (Table 1$)$. The difference in this ratio either reflected (1) the poorer quality of residues left behind following harvest with unfertilized perennial grass systems or (2) the more incomplete state of decomposition of substrates provided by perennial grass systems because of lower soil moisture (see later).

For the most part, the more active fractions of organic matter (i.e. soil microbial biomass $\mathrm{C}$ and potential $\mathrm{N}$ mineralization) were greater under perennial grass systems than under annual cropping systems $(P<0.01)$, similar to the response of total organic $\mathrm{C}$ (Table 1). Light-fraction $\mathrm{C}$ and $\mathrm{N}$ were not different between the group-wise comparison of perennial and annual cropping systems. The difference between perennial and annual cropping systems averaged $16 \%$ for total organic C, $27 \%$ for soil microbial biomass C, and $50 \%$ for potential $\mathrm{N}$ mineralization. This increasing degree of relative change with more active fractions of organic matter was similar to that reported at a nearby site comparing medium-term changes due to tillage management (Franzluebbers and Arshad, 1996a).

Soil physical properties under perennial grass systems tended to be slightly improved compared with those under annual cropping systems (Tables 2 and 3). Rate of water infiltration, fraction of soil as large macroaggregates $(>1 \mathrm{~mm})$, and mean-weight diameter of water-stable aggregates were greater under 
Table 2

Water-stable aggregate (WSA) distribution, mean-weight diameter, and $\mathrm{C}$ and $\mathrm{N}$ concentrations of water-stable aggregate fractions from surface soil $(0-10 \mathrm{~cm})$ at the end of 11 years of management as affected by cropping system near Beaverlodge, Alta.

\begin{tabular}{|c|c|c|c|c|c|c|c|}
\hline \multirow[t]{2}{*}{ Soil property } & \multirow{2}{*}{$\begin{array}{l}\text { Smooth } \\
\text { brome }\end{array}$} & \multirow{2}{*}{$\begin{array}{l}\text { Red } \\
\text { fescue }\end{array}$} & \multirow{2}{*}{$\begin{array}{l}\text { Continuous } \\
\text { wheat }\end{array}$} & \multicolumn{3}{|c|}{ 3-Year rotation of } & \multirow[t]{2}{*}{$\operatorname{LSD}_{(\mathrm{P} \leq 0.05)}$} \\
\hline & & & & $\begin{array}{l}\text { Wheat-wheat- } \\
\text { canola }\end{array}$ & $\begin{array}{l}\text { Wheat-wheat- } \\
\text { pea }\end{array}$ & $\begin{array}{l}\text { Wheat-wheat- } \\
\text { fallow }\end{array}$ & \\
\hline WSA mass, $1-8 \mathrm{~mm}\left(\mathrm{~g} \mathrm{~g}^{-1}\right)$ & 0.56 & 0.53 & 0.45 & 0.40 & 0.41 & 0.41 & 0.09 \\
\hline WSA mass, $0.25-1 \mathrm{~mm}\left(\mathrm{~g} \mathrm{~g}^{-1}\right)$ & 0.29 & 0.27 & 0.27 & 0.35 & 0.30 & 0.32 & 0.05 \\
\hline WSA mass, $<0.25 \mathrm{~mm}\left(\mathrm{~g} \mathrm{~g}^{-1}\right)$ & 0.16 & 0.20 & 0.28 & 0.25 & 0.29 & 0.27 & 0.07 \\
\hline Mean-weight diameter (mm) & 2.1 & 2.2 & 1.8 & 1.5 & 1.7 & 1.6 & 0.4 \\
\hline Aggregate $\mathrm{C}, 1-8 \mathrm{~mm}\left(\mathrm{~g} \mathrm{~kg}^{-1}\right)$ & 18 & 19 & 16 & 15 & 15 & 15 & 3 \\
\hline Aggregate $\mathrm{C}, 0.25-1 \mathrm{~mm}\left(\mathrm{~g} \mathrm{~kg}^{-1}\right)$ & 10 & 10 & 11 & 14 & 11 & 12 & 2 \\
\hline Aggregate $\mathrm{C},<0.25 \mathrm{~mm}\left(\mathrm{~g} \mathrm{~kg}^{-1}\right)$ & 15 & 15 & 11 & 10 & 10 & 10 & 4 \\
\hline Aggregate $\mathrm{N}, 1-8 \mathrm{~mm}\left(\mathrm{~g} \mathrm{~kg}^{-1}\right)$ & 2.0 & 1.9 & 1.7 & 1.5 & 1.5 & 1.5 & 0.4 \\
\hline Aggregate $\mathrm{N}, 0.25-1 \mathrm{~mm}\left(\mathrm{~g} \mathrm{~kg}^{-1}\right)$ & 1.1 & 1.0 & 1.0 & 1.4 & 1.2 & 1.2 & 0.2 \\
\hline Aggregate $\mathrm{N},<0.25 \mathrm{~mm}\left(\mathrm{~g} \mathrm{~kg}^{-1}\right)$ & 0.6 & 0.7 & 1.2 & 0.9 & 1.1 & 1.2 & 0.5 \\
\hline
\end{tabular}

perennial than under annual cropping systems $(P<$ $0.01)$. The fraction of soil as small macroaggregates $(0.25-1 \mathrm{~mm})$ and as microaggregates $(<0.25 \mathrm{~mm})$ was lower under perennial grass than under annual cropping systems $(P=0.03$ and $P=0.001$, respectively). Soil bulk density was not different, but penetration resistance was greater under perennial than under annual cropping systems at several soil depth increments. The only negative change in soil physical properties with perennial grass management was due to increased penetration resistance, particularly at the soil surface. This may have been due to lower soil water content at the time of sampling under perennial than under annual cropping. Penetration resistance and soil water content are inversely related (Busscher et al., 1997), suggesting that if soil moisture conditions were similar there may not have been a significant change in soil penetration resistance between the perennial and annual cropping systems.

The positive effect of perennial grass systems compared with annual cropping systems on total organic $\mathrm{C}$ could be isolated as increases in $\mathrm{C}$ within large macroaggregates $(>1 \mathrm{~mm})(P=0.03)$ and microaggregates $(<0.25 \mathrm{~mm})(P=0.01)$ and a decrease

Table 3

Bulk density of surface soil $(0-10 \mathrm{~cm})$ in October 2001, water infiltration in September 2002, and soil penetration resistance and water content in June 2002 as affected by cropping system near Beaverlodge, Alta.

\begin{tabular}{|c|c|c|c|c|c|c|c|}
\hline \multirow[t]{2}{*}{ Soil property } & \multirow{2}{*}{$\begin{array}{l}\text { Smooth } \\
\text { brome }\end{array}$} & \multirow{2}{*}{$\begin{array}{l}\text { Red } \\
\text { fescue }\end{array}$} & \multirow{2}{*}{$\begin{array}{l}\text { Continuous } \\
\text { wheat }\end{array}$} & \multicolumn{3}{|c|}{3 -Year rotation of } & \multirow[t]{2}{*}{$\operatorname{LSD}_{(\mathrm{P} \leq 0.05)}$} \\
\hline & & & & $\begin{array}{l}\text { Wheat-wheat- } \\
\text { canola }\end{array}$ & $\begin{array}{l}\text { Wheat-wheat- } \\
\text { pea }\end{array}$ & $\begin{array}{l}\text { Wheat-wheat- } \\
\text { fallow }\end{array}$ & \\
\hline Bulk density $\left(\mathrm{Mg} \mathrm{m}^{-3}\right)$ & 1.20 & 1.12 & 1.20 & 1.19 & 1.17 & 1.17 & 0.11 \\
\hline Water infiltration $\left(\mathrm{mm} \mathrm{h}^{-1}\right)$ & 0.23 & 0.17 & 0.13 & 0.18 & 0.17 & 0.13 & 0.16 \\
\hline Resistance, $0-5 \mathrm{~cm}(\mathrm{MPa})$ & 2.3 & 2.4 & 1.3 & 1.4 & 1.5 & 1.3 & 0.7 \\
\hline Resistance, $10-15 \mathrm{~cm}(\mathrm{MPa})$ & 2.1 & 1.6 & 1.7 & 1.8 & 1.8 & 1.4 & 0.4 \\
\hline Resistance, 20-25 cm (MPa) & 2.4 & 2.0 & 2.0 & 2.5 & 1.8 & 1.5 & 0.4 \\
\hline Resistance, $30-35 \mathrm{~cm}(\mathrm{MPa})$ & 2.9 & 2.2 & 2.6 & 2.9 & 2.2 & 1.8 & 0.7 \\
\hline Resistance, $40-45 \mathrm{~cm}(\mathrm{MPa})$ & 4.5 & 3.1 & 4.0 & 4.5 & 3.4 & 2.7 & 1.3 \\
\hline Soil water, $0-5 \mathrm{~cm}\left(\mathrm{~g} \mathrm{~g}^{-1}\right)$ & 0.19 & 0.28 & 0.28 & 0.23 & 0.28 & 0.27 & 0.05 \\
\hline Soil water, $10-15 \mathrm{~cm}\left(\mathrm{~g} \mathrm{~g}^{-1}\right)$ & 0.22 & 0.29 & 0.27 & 0.27 & 0.30 & 0.28 & 0.04 \\
\hline Soil water, $20-25 \mathrm{~cm}\left(\mathrm{~g} \mathrm{~g}^{-1}\right)$ & 0.23 & 0.27 & 0.27 & 0.24 & 0.26 & 0.28 & 0.08 \\
\hline Soil water, $30-35 \mathrm{~cm}\left(\mathrm{~g} \mathrm{~g}^{-1}\right)$ & 0.22 & 0.26 & 0.26 & 0.25 & 0.30 & 0.29 & 0.05 \\
\hline Soil water, $40-45 \mathrm{~cm}\left(\mathrm{~g} \mathrm{~g}^{-1}\right)$ & 0.24 & 0.29 & 0.25 & 0.23 & 0.25 & 0.29 & 0.04 \\
\hline
\end{tabular}


in small macroaggregates $(0.25-1 \mathrm{~mm})(P=0.05)$ (Table 2). Total $\mathrm{N}$ of large macroaggregates $(>1 \mathrm{~mm})$ under perennial grass systems was also greater than under annual cropping systems $(P=0.01)$. However, the lower whole-soil total $\mathrm{N}$ concentration under perennial grass systems compared with annual cropping systems (Table 1) occurred due to a non-significant reduction in small macroaggregates and a significant reduction in microaggregates $(<0.25 \mathrm{~mm})(P=0.01)$. These results corroborate previous literature, suggesting that sequestration of organic $\mathrm{C}$ and $\mathrm{N}$ with no-tillage occurs preferentially in macroaggregates (Cambardella and Elliott, 1993; Franzluebbers and Arshad, 1996b).

There were very few differences in soil properties between smooth brome and red fescue. A notable difference between perennial crops was lower penetration resistance below $10 \mathrm{~cm}$ due to higher soil water content under red fescue compared with smooth brome (Table 3 ). Red fescue rooting activity could be considered less aggressive than smooth brome in this region, resulting in moist soil for a longer period of time.

\subsection{Comparisons among wheat rotations}

Except for light-fraction $\mathrm{C}$ and $\mathrm{N}$, none of the chemical and biochemical soil properties were significantly affected by wheat rotation system. Light-fraction $\mathrm{C}$ and $\mathrm{N}$ were both greater under continuous wheat than under other crop rotations, but especially greater than under the rotation with fallow (Table 1). Continuous wheat straw input each year has been shown to improve light-fraction $\mathrm{C}$ and $\mathrm{N}$ in other studies from western Canada (Janzen et al., 1998; Liang et al., 2002).

Small macroaggregates $(0.25-1 \mathrm{~mm})$ under the wheat-wheat-canola rotation contained greater quantities of $\mathrm{C}$ and $\mathrm{N}$ than under wheat-wheat-pea and continuous wheat (Table 2). It is not clear why this would have occurred.

Few significant changes in soil physical properties occurred due to wheat rotation system (Tables 2 and 3). Penetration resistance was lower in wheatwheat-fallow rotation below $10 \mathrm{~cm}$ compared with other wheat rotations, which could be attributed in most cases to higher soil water content (Table 3). These measurements in June 2002 were taken from under the first wheat crop following either fallow, canola, pea, or wheat. Therefore, the lower resistance and higher water content in the fallow rotation could be attributed to moisture conservation accumulated during the previous year.

The overall lack of significant differences among wheat rotation systems suggests that relatively small diversity changes during a 3-year rotation sequence under no-tillage in this cold, semiarid environment had little effect on long-term soil properties. These results contrast with several previous studies that indicate significant changes in soil organic $\mathrm{C}$ and biological activity with crop rotations, especially with bare fallow in the rotation (Campbell et al., 1995, 1999; Peterson et al., 1998). The reason our results differed from those of others may be a result of differences in tillage management. There are few studies available for comparison, but no-tillage management of crop rotations may be a variable that subdues effects of crop diversity on soil physical, chemical, and biological properties. In support of this hypothesis, the coefficient of variation among crop rotations was greater under conventional tillage than under no-tillage for the portion of $\mathrm{C}$ input sequestered as soil organic $\mathrm{C}(45 \%$ versus $7 \%)$ and for potential C mineralization $(21 \%$ versus $16 \%)$ in a 10 -year study in Texas (Franzluebbers et al., 1998). Further, the relative difference in soil properties due to crop rotation was similar between conventional and no-tillage management systems for soil organic $\mathrm{C}$ and $\mathrm{N}$, but greater under conventional tillage for soil microbial biomass $\mathrm{C}$ and potential $\mathrm{C}$ mineralization (Campbell et al., 1999). As a contrast to this hypothesis, the coefficient of variation in soil properties among crop rotations in long-term plots in Ohio was lower under conventional tillage than under no-tillage for bulk density and aggregation (Lal et al., 1994) and for various soil enzyme activities (Dick, 1984).

\subsection{Relationships among soil properties}

Among 11 soil properties measured during the 11th year of this study, soil microbial biomass $\mathrm{C}$ was significantly correlated with the most other properties (i.e. 7) (Table 4). The number of significant correlations with other soil properties was six for soil organic $\mathrm{C}$ and large macroaggregates $(>1 \mathrm{~mm})$ and five for microaggregates $(<0.25 \mathrm{~mm})$, light-fraction $\mathrm{C}$ and $\mathrm{N}$, and potential $\mathrm{N}$ mineralization. The strongest correlation oc- 
Table 4

Correlation matrix among soil physical, chemical, and biological properties collected at the end of 11 years of management in August and September $2002(0-10 \mathrm{~cm}$ depth $)(n=36)$

\begin{tabular}{llllllrrrrrr}
\hline Soil property & BD & MWD & LMA & SMA & MICRO & SOC & TSN & LFC & LFN & PMN & SMBC \\
\hline BD & - & -0.12 & -0.20 & 0.15 & 0.14 & -0.20 & 0.28 & 0.19 & 0.16 & -0.16 & -0.38 \\
MWD & $\mathrm{ns}$ & - & 0.85 & 0.63 & -0.61 & 0.19 & -0.22 & -0.07 & -0.07 & 0.24 & 0.43 \\
LMA & $\mathrm{ns}$ & $* * *$ & - & -0.61 & -0.81 & 0.34 & -0.15 & 0.01 & 0.02 & 0.34 & 0.52 \\
SMA & $\mathrm{ns}$ & $* * *$ & $* * *$ & - & 0.03 & 0.15 & 0.40 & 0.11 & 0.14 & -0.14 & -0.16 \\
MICRO & $\mathrm{ns}$ & $* * *$ & $* * *$ & $\mathrm{~ns}$ & - & -0.54 & -0.10 & -0.09 & -0.12 & -0.34 & -0.52 \\
SOC & $\mathrm{ns}$ & $\mathrm{ns}$ & + & $\mathrm{ns}$ & $* * *$ & - & 0.12 & 0.53 & 0.56 & 0.42 & 0.73 \\
TSN & $\mathrm{ns}$ & $\mathrm{ns}$ & $\mathrm{ns}$ & + & $\mathrm{ns}$ & $\mathrm{ns}$ & - & 0.31 & 0.28 & -0.08 & -0.03 \\
LFC & $\mathrm{ns}$ & $\mathrm{ns}$ & $\mathrm{ns}$ & $\mathrm{ns}$ & $\mathrm{ns}$ & $* * *$ & + & - & 0.98 & 0.29 & 0.32 \\
LFN & $\mathrm{ns}$ & $\mathrm{ns}$ & $\mathrm{ns}$ & $\mathrm{ns}$ & $\mathrm{ns}$ & $* * *$ & + & $* * *$ & - & 0.28 & 0.33 \\
NMIN & $\mathrm{ns}$ & $\mathrm{ns}$ & + & $\mathrm{ns}$ & + & $* *$ & $\mathrm{~ns}$ & + & + & - & 0.27 \\
MBC & + & $* *$ & $* * *$ & $\mathrm{~ns}$ & $* * *$ & $* * *$ & $\mathrm{~ns}$ & + & + & $\mathrm{ns}$ & -
\end{tabular}

${ }^{a}$ BD: bulk density ( $\mathrm{Mg} \mathrm{m}^{-3}$ soil); MWD: mean-weight diameter following slaking in water (mm); LMA: large water-stable macroaggregates, >1 mm ( $\mathrm{g} \mathrm{g}^{-1}$ soil); SMA: small water-stable macroaggregates, $0.25-1.0 \mathrm{~mm}\left(\mathrm{~g} \mathrm{~g}^{-1}\right.$ soil); MICRO: microaggregates $<0.25 \mathrm{~mm}\left(\mathrm{~g} \mathrm{~g}^{-1}\right.$ soil); SOC: soil organic carbon ( $\mathrm{g} \mathrm{kg}^{-1}$ soil); TSN: total soil nitrogen $\left(\mathrm{g} \mathrm{g}^{-1}\right.$ soil); LFC: light-fraction C ( $\mathrm{g} \mathrm{g}^{-1}$ soil); LFN: light-fraction $\mathrm{N}$ ( $\mathrm{g} \mathrm{g}^{-1}$ soil); NMIN: potential nitrogen mineralization $\left(\mathrm{mg} \mathrm{kg}^{-1}\right.$ soil per 24 days); MBC: soil microbial biomass carbon (mg $\mathrm{g}^{-1}$ soil).

${ }^{\mathrm{b}}$ ns: not significant.

** Significant at $P \leq 0.01$.

*** Significant at $P \leq 0.001$.

+ Significant at $P \leq 0.1$.

curred between light-fraction $\mathrm{C}$ and light-fraction $\mathrm{N}$, indicating the connection between light-fraction quantity and quality. It is interesting to note that the correlation between whole-soil $\mathrm{C}$ and $\mathrm{N}$ was not at all significant, indicating the uncoupling in organic matter dynamics that occurred because of differences in $\mathrm{C}$ inputs and $\mathrm{N}$ inputs between previously unfertilized perennial grass systems and continuously well-fertilized annual cropping systems.

Strong positive correlations occurred between mean-weight diameter and large and small macroaggregates, primarily because of the high concentration of macroaggregates and the large influence that these larger diameter aggregates have on the calculation of mean-weight diameter (Table 4). The negative relationship of microaggregates with large macroaggregates was likely due simply to elimination, i.e. if soil macroaggregates remained water-stable then this precluded them from contributing to the microaggregate pool. The negative relationship of microaggregates with soil organic and microbial biomass $\mathrm{C}$ indicates that microaggregates $(<0.25 \mathrm{~mm})$ did not accumulate total and biologically active organic matter pools to the same degree that macroaggregates $(>0.25 \mathrm{~mm})$ did. Slaking of soil in water often leads to macroaggregates enriched in C pools compared with microaggregates (Elliott, 1986; Beare et al., 1994; Franzluebbers and Arshad, 1997).

Soil organic $\mathrm{C}$ had strong positive correlations with light-fraction $\mathrm{C}$ and $\mathrm{N}$ and soil microbial biomass $\mathrm{C}$, which are relatively small, but key biologically active components of soil organic matter. Strong correlations among these organic matter pools have been reported before (Janzen et al., 1992; Biederbeck et al., 1994; Franzluebbers et al., 1994).

\section{Conclusions}

At the end of 10 years of management, surface-soil $(0-10 \mathrm{~cm})$ aggregation was at a state to resist water erosion more under perennial grass (i.e. bromegrass and red fescue) than under annual cropping systems. It is likely that continuous vegetative cover throughout the year and vigorous root growth helped preserve organic matter and promote aggregation. There were few significant differences in soil-structural properties among the various annual cropping systems. The largest effect was greater light-fraction $\mathrm{C}$ and $\mathrm{N}$ under continuous wheat compared with other rotations, 
especially wheat-wheat-fallow, as a result of higher residue inputs. Despite somewhat lower quality of soil with annual than with perennial cropping systems, high productivity of cereal production could be achieved with little indication of dramatic detriment to the soil and the surrounding environment, should conservation tillage management without bare fallow be employed.

\section{Acknowledgements}

The technical expertise of Anwar Haq is appreciated.

\section{References}

Angers, D.A., Pesant, A., Vigneux, J., 1992. Early croppinginduced changes in soil aggregation, organic matter, and microbial biomass. Soil Sci. Soc. Am. J. 56, 115-119.

Arshad, M.A., Gill, K.S., Izaurralde, R.C., 1998. Wheat production, weed population and soil properties subsequent to 20 years of sod as affected by crop rotation and tillage. J. Sustain. Agric. $12,131-154$.

Arshad, M.A., Soon, Y.K., Azooz, R.H., 2002. Modified no-till and crop sequence effects on spring wheat production in northern Alberta, Canada. Soil Till. Res. 65, 29-36.

Beare, M.H., Hendrix, P.F., Coleman, D.C., 1994. Water-stable aggregates and organic matter fractions in conventional- and no-tillage soils. Soil Sci. Soc. Am. J. 58, 777-786.

Biederbeck, V.O., Janzen, H.H., Campbell, C.A., Zentner, R.P., 1994. Labile soil organic matter as influenced by cropping practices in an arid environment. Soil Biol. Biochem. 26, 16471656.

Bremner, J.M., 1996. Nitrogen-total. In: Sparks, D.L. (Ed.), Methods of Soil Analysis. Part 3. Chemical Methods. Soil Sci. Soc. Am., Madison, WI, pp. 1085-1121.

Bundy, L.G., Meisinger, J.J., 1994. Nitrogen availability indices. In: Weaver, R.W., Angle, J.S., Bottomley, P.S. (Eds.), Methods of Soil Analysis. Part 2. Microbiological and Biochemical Properties. Soil Sci. Soc. Am., Madison, WI, pp. 951-984.

Busscher, W.J., Bauer, P.J., Camp, C.R., Sojka, R.E., 1997. Correction of cone index for soil water content differences in a coastal plain soil. Soil Till. Res. 43, 205-217.

Cambardella, C.A., Elliott, E.T., 1993. Carbon and nitrogen distribution in aggregates from cultivated and native grassland soils. Soil Sci. Soc. Am. J. 57, 1071-1076.

Campbell, C.A., Zentner, R.P., Janzen, H.H., Bowren, K.E., 1990. Crop rotation studies on the Canadian prairie. Publication No. 1841/E, Agriculture Canada, Res. Br., Ottawa, 133 pp.

Campbell, C.A., McConkey, B.G., Zentner, R.P., Selles, F., Curtin, D., 1996. Long-term effects of tillage and crop rotations on soil organic $\mathrm{C}$ and total $\mathrm{N}$ in a clay soil in southwestern Saskatchewan. Can. J. Soil Sci. 76, 396-401.
Campbell, C.A., Biederbeck, V.O., McConkey, B.G., Curtin, D., Zentner, R.P., 1999. Soil quality-effect of tillage and fallow frequency. Soil organic matter quality as influenced by tillage and fallow frequency in a silt loam in southwestern Saskatchewan. Soil Biol. Biochem. 31, 1-7.

Campbell, C.A., McConkey, B.G., Zentner, R.P., Dyck, F.B., Selles, F., Curtin, D., 1995. Carbon sequestration in a Brown Chemozem as affected by tillage and rotation. Can. J. Soil Sci. 75, 449-458.

Chan, K.Y., Mead, J.A., 1986. Surface physical properties of a sandy soil under different tillage practices. Aust. J. Soil Res. 26, 549-559.

Cihacek, L.J., Meyer, D.W., 2002. Influence of nitrogen fertility management on profile soil carbon storage under long-term bromegrass production. In: Kimble, J.M., Lal, R., Follett, R.F. (Eds.), Agricultural Practices and Policies for Carbon Sequestration in Soil. Lewis Publication, Boca Raton, FL, pp. 281-286.

Dick, W.A., 1984. Influence of long-term tillage and crop rotation combinations on soil enzyme activities. Soil Sci. Soc. Am. J. 48, 569-574.

Elliott, E.T., 1986. Aggregate structure and carbon, nitrogen, and phosphorus in native and cultivated soils. Soil Sci. Soc. Am. J. 50, 627-633.

Franzluebbers, A.J., Arshad, M.A., 1996a. Soil organic matter pools with conventional and zero tillage in a cold, semiarid climate. Soil Till. Res. 39, 1-11.

Franzluebbers, A.J., Arshad, M.A., 1996b. Water-stable aggregation and organic matter in four soils under conventional and zero tillage. Can. J. Soil Sci. 76, 387-393.

Franzluebbers, A.J., Arshad, M.A., 1997. Soil microbial biomass and mineralizable carbon of water-stable aggregates. Soil Sci. Soc. Am. J. 61, 1090-1097.

Franzluebbers, A.J., Haney, R.L., Hons, F.M., 1999. Relationships of chloroform fumigation-incubation to soil organic matter pools. Soil Biol. Biochem. 31, 395-405.

Franzluebbers, A.J., Hons, F.M., Zuberer, D.A., 1994. Long-term changes in soil carbon and nitrogen pools in wheat management systems. Soil Sci. Soc. Am. J. 58, 1639-1645.

Franzluebbers, A.J., Hons, F.M., Zuberer, D.A., 1998. In situ and potential $\mathrm{CO}_{2}$ evolution from a Fluventic Ustochrept in southcentral Texas as affected by tillage and cropping intensity. Soil Till. Res. 47, 303-308.

Franzluebbers, A.J., Stuedemann, J.A., Schomberg, H.H., Wilkinson, S.R., 2000. Soil organic C and N pools under longterm pasture management in the southern Piedmont, USA. Soil Biol. Biochem. 32, 469-478.

Haas, H.J., Evans, C.E., Miles, E.F., 1957. Nitrogen and carbon changes in Great Plains soils as influenced by cropping and soil treatments. USDA Tech. Bull. 1164. US Government Printing Office, Washington, DC.

Ismail, I., Blevins, R.L., Frye, W.W., 1994. Long-term no-tillage effects on soil properties and continuous com yields. Soil Sci. Soc. Am. J. 58, 193-198.

Jansson, S.L., Persson, J., 1982. Mineralization and immobilization of soil nitrogen. In: Stevenson, F.J. (Ed.), Nitrogen in Agricultural Soils. Agron. No. 22, Am. Soc. Agron., Crop Sci. Soc. Am., Soil Sci. Soc. Am., Madison, WI, pp. 229-252. 
Janzen, H.H., 1987. Soil organic matter characteristics after longterm cropping to various spring wheat rotations. Can. J. Soil Sci. 67, 845-856.

Janzen, H.H., Campbell, C.A., Brandt, S.A., Lafond, G.P., Townley-Smith, L., 1992. Light-fraction organic matter in soils from long-term crop rotations. Soil Sci. Soc. Am. J. 56, 17991806.

Janzen, H.H., Campbell, C.A., Izaurralde, R.C., Ellert, B.H., Juma, N., McGill, W.B., Zentner, R.P., 1998. Management effects on soil C storage on the Canadian prairies. Soil Till. Res. 47, 181-195.

Jenkinson, D.S., Powlson, D.S., 1976. The effects of biocidal treatment on metabolism in soil. V. A method for measuring soil biomass. Soil Biol. Biochem. 8, 209-213.

Karlen, D.L., Cambardella, C.A., 1996. Conservation strategies for improving soil quality and organic matter storage. In: Carter, M.R., Stewart, B.A. (Eds.), Structure and Organic Matter Storage in Agricultural Soils. Lewis Publication, Boca Raton, FL, pp. 395-420.

Kemper, W.D., Rosenau, R.C., 1986. Aggregate stability and size distribution. In: Klute, A. (Ed.), Methods of Soil Analysis, Part 1, 2nd ed. Am. Soc. Agron., Soil Sci. Soc. Am., Madison, WI, pp. 425-442.

Lal, R., Mahboubi, A.A., Fausey, N.R., 1994. Long-term tillage and rotation effects on properties of a central Ohio soil. Soil Sci. Soc. Am. J. 58, 517-522.

Liang, B.C., McConkey, B.G., Campbell, C.A., Johnston, A.M., Moulin, A.P., 2002. Short-term crop rotation and tillage effects on soil organic carbon on the Canadian prairies. In: Kimble, J.M., Lal, R., Follett, R.F. (Eds.), Agricultural Practices and Policies for Carbon Sequestration in Soil. Lewis Publication, Boca Raton, FL, pp. 287-293.
McGill, W.B., Cannon, K.R., Robertson, J.A., Cook, F.D., 1986. Dynamics of soil microbial biomass and water soluble $\mathrm{C}$ in Breton L after 51 years of cropping to two rotations. Can. J. Soil Sci. 66, 1-19.

Nelson, D.W., Sommers, L.E., 1996. Total carbon, organic carbon, and organic matter. In: Sparks, D.L. (Ed.), Methods of Soil Analysis. Part 3. Chemical Methods. Soil Sci. Soc. Am., Madison, WI, pp. 961-1010.

Nyborg, M., Molina-Ayala, M., Solberg, E.D., Izaurralde, R.C., Malhi, S.S., Janzen, H.H., 1997. Carbon storage in grassland soils as related to $\mathrm{N}$ and $\mathrm{S}$ fertilizers. In: Lal, R., Kimble, J.M., Follett, R.F., Stewart, B.A. (Eds.), Management of Carbon Sequestration in Soil. CRC Press, Boca Raton, FL, pp. 421-432.

Peterson, G.A., Halvorson, A.D., Havlin, J.L., Jones, O.R., Lyon, D.J., Tanaka, D.L., 1998. Reduced tillage and increasing cropping intensity in the Great Plains conserves soil C. Soil Till. Res. 47, 207-218.

Reynolds, W.D., Elrick, D.E., Clothier, B.E., 1985. The constanthead well permeameter: effect of unsaturated flow. Soil Sci. 139, 172-180.

SAS Institute Inc., 1990. SAS User's Guide: Statistics, Version 6. SAS Institute Inc., Cary, NC.

Soil Classification Working Group, 1998. The Canadian System of Soil Classification, 3rd ed. NRC Research Press, Ottawa.

Soil Survey Staff, 1996. USDA Keys to Soil Taxonomy, 7th ed. USDA, Soil Conservation Service, Washington, DC.

Strickland, T.C., Sollins, P., 1987. Improved method for separating light- and heavy-fraction organic material from soil. Soil Sci. Soc. Am. J. 51, 1390-1393.

Voroney, R.P., Paul, E.A., 1984. Determination of $\mathrm{kC}$ and $\mathrm{kN}$ in situ for calibration of the chloroform fumigation-incubation method. Soil Biol. Biochem. 16, 9-14. 